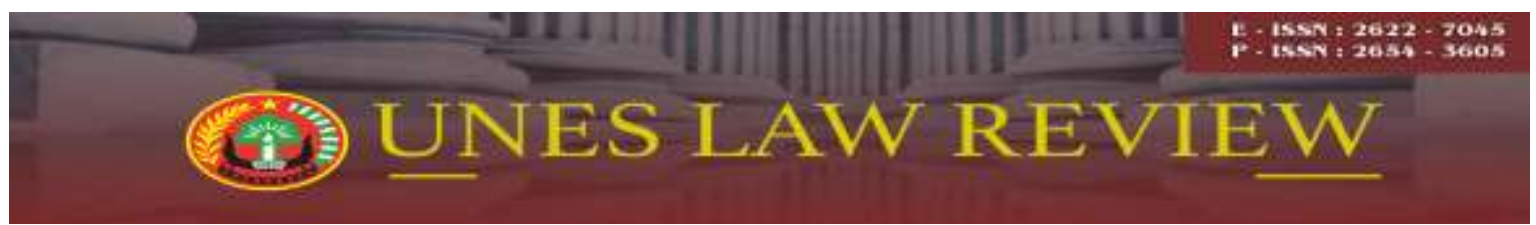

Email: uneslawreview@gmail.com

Online: http://review-unes.com/index.php/law

Volume 2, Issue 1, September 2019

\title{
PENERAPAN PIDANA TERHADAP ANAK PELAKU TINDAK PIDANA PERSETUBUHAN (Studi Putusan Nomor 3/Pid.Sus-Anak/2018/PN.Pmn dan Putusan Nomor 11/Pid.Sus-Anak/2018/PN.Pmn)
}

\author{
Rr. Rahmani Endah Koesoemowardani \\ Pengadilan Negeri Pariaman, Sumatera Barat, Indonesia \\ E-mail : endah65@gmail.com
}

\begin{abstract}
The verification of this crime is often not carried out properly, because the child of the victim of sexual intercourse feels embarrassed and afraid of the perpetrators, which influences the judgment of the judge and the application of the law. The criminal application of the Pariaman District Court Number 3 / Pid. . Pmn and Number 11 / Pid. Sus-Anak / 2018 / PN.Pmn is the criminal application of children as perpetrators of sexual intercourse in decision Number 3 / Pid.sus anak / 2018 / PN Pmn and Number 11 / Pid. Sus- Anak / 2018 / PN Pmn, Based on the legal facts revealed in the trial fulfilled the elements contained in Article 81 paragraph (2) of Law Number 35 Year 2014 concerning amendments to Law Number 23 of 2002 concerning Child Protection. Judicial legal considerations in imposing criminal sanctions on imprisonment against children are legal judicial considerations and social conditions of children and their environment.
\end{abstract}

Kata Kunci: Penerapan Pidana, Pertimbangan Hakim, Putusan Pengadilan

\section{PENDAHULUAN}

Undang-Undang Nomor 11 Tahun 2012 tentang Sistem Peradilan Pidana Anak dalam asas-asasnya menekankan pada perlindungan, keadilan, non diskriminasi, kepentingan terbaik bagi anak, penghargaan terhadap pendapat anak, kelangsungan hidup dan tumbuh kembang anak, pembinaan dan pembimbingan anak, proposional, perampasan kemerdekaan dan pemidanaan sebagai upaya terakhir dan penghindaran pembalasan serta mengutamakan pendekatan keadilan.

Adanya pembaharuan double track system sebagai sistem sanksi dan pembaharuan sanksi pidana tersistematis yang berkarakter tindakan. Hakikat double track system yaitu fungsi sanksi pidana tidaklah semata-mata menakut-nakuti atau mengancam, akan tetapi lebih dari itu keberadaan sanksi tersebut harus juga dapat mendidik dan memperbaiki sipelanggar (Sholehuddin, 2004: 162). 
Khusus untuk sanksi pidana pokok juga lebih bervariasi sebagaimana Pasal 71 Undang-Undang Nomor 11 Tahun 2012 yang meliputi pidana peringatan, pembinaan di luar lembaga, pelayanan masyarakat, pengawasan, pelatihan kerja, pembinaan dalam lembaga dan penjara. Selain itu, pada sanksi pidana tambahan terdapat juga perubahan berupa perampasan keuntungan yang diperoleh dari tindak pidana dan pemenuhan kewajiban adat. Setiap pelaksanaan pidana, diharapkan tidak menimbulkan korban, penderitaan, kerugian mental, fisik dan sosial maka pidana dan tindakan harus bertujuan edukatif, konstruktif, tidak destruktif dan disamping itu harus pula memenuhi kepentingan anak yang bersangkutan (Maidin, 2010: 124). Undang-Undang Nomor 11 Tahun 2012 tidak hanya memberikan jaminan perlindungan terhadap anak yang melakukan perbuatan pidana dengan memperhatikan ciri maupun sifat yang khas pada anak.

Dari segi pengaturan sistem sanksi, khususnya terkait pidana pokok dalam UndangUndang Nomor 11 Tahun 2012 yang memuat sanksi pidana dan sanksi tindakan tidak serta merta dapat dijatuhkan secara acak karena harus memperhatikan pedoman pemidanaan yang telah diatur dalam undang-undang tersebut, kebutuhan anak itu sendiri, rasa keadilan dalam masyarakat, serta kepastian hukum. Kewenangan untuk menjatuhkan sanksi-sanksi pidana khususnya pidana pokok merupakan kewenangan hakim.Hakim harus menjatuhkan pidana dalam putusannya sesuai dengan kondisi anak dan rasa keadilan masyarakat (Sutatiek, 2013: 46).

Berdasarkan latar belakang pemikiran yang telah dipaparkan di atas, maka rumusanpermasalahan adalah bagaimanakah penerapan pidana dan bagaimanakah pertimbangan Hakim terhadap Anak pelaku tindak pidana persetubuhan Studi Putusan Nomor 3/Pid.Sus-Anak/2018/PN.Pmn dan PutusanNomor 11/Pid.SusAnak/2018/PN.Pmn?

\section{METODE PENELITIAN}

Spesifikasi penelitian adalah deskriptif analisis,dengan metode pendekatanyuridis normatif. Jenis data yang digunakan adalah data sekunder.Data sekunder diperoleh dari studi dokumen dan studi kepustakaan. Teknik pengumpulan data pada data sekunder dilakukan dengan studi kepustakaan. Data yang diperoleh kemudian dianalisa secara kualitatif . 


\section{HASIL PENELITIAN}

\section{Penerapan pidana oleh Hakim terhadap anak pelaku tindak pidana persetubuhan dalam putusan Nomor 3/Pid.Sus-Anak/2018/PN Pmn dan nomor 11/Pid.Sus- Anak/2018/PN Pmn.}

Pada putusan Hakim harus diuraikan fakta dan keadaan yang berhubungan dengan peristiwa pidana yang dilakukan terdakwa dengan jelas sesuai dengan apa yang terungkap dalam pemeriksaan sidang pengadilan. Mengenai pembuktian yang diperoleh dari pemeriksaan di sidang pengadilan yang menjadi dasar penentuan kesalahan terdakwa, dipergunakan sebagai titik tolak untuk pertimbangan berat ringannya hukuman pidana yang dijatuhkan kepada terdakwa.

Berdasarkan tuntutan pidana Jaksa Penuntut Umum tersebut, Hakim Pengadilan Negeri Pariaman atas dasar fakta-fakta hukum yang terungkap dipersidangan sebagai dasar untuk memberikan pertimbangan-pertimbangan hukum dengan putusan kepada anak yaituAnak telah terbukti secara sah dan meyakinkan bersalah melakukan tindak pidana "Dengan Sengaja membujuk anak untuk melakukan persetubuhan dengannya. Pada putusan ini Hakim berpendapat sama dengan tuntutan yang diajukan oleh Jaksa penuntut Umum, dimana anak dinyatakan bersalah telah melanggar Pasal 81 ayat (2) UndangUndang Nomor 35 tahun 2014 Tentang Perubahan atas Undang-Undang RI Nomor 23 Tahun 2002 tentang Perlindungan Anak yang berbunyi: “ Ketentuan pidana sebagaimana dimaksud pada ayat (1) berlaku pula bagi Setiap Orang yang dengan sengaja melakukan tipu muslihat, serangkaian kebohongan, atau membujuk Anak melakukan persetubuhan dengannya atau dengan orang lain".

Berdasarkan putusan Hakim yang menyatakan anak bersalah karena melakukan perbuatan yang melanggar Pasal 81 ayat (2) Undang-Undang Nomor 35 tahun 2014 Tentang Perubahan atas Undang-Undang RI Nomor 23 Tahun 2002 tentang Perlindungan Anak maka unsur unsur yang terpenuhi pada Pasal tersebut adalah :

1) Setiap orang.

2) Dengan sengaja.

3) Melakukan tipu muslihat, serangkaian kebohongan, atau membujuk anak.

4) Melakukan persetubuhan dengannya atau dengan orang lain. 
Pada Perkara nomor 11/Pid.Sus-Anak/2018/PN Pmn terdapat unsur yang sama karena pada perkara ini terdakwa juga diputus bersalah melanggar Pasal 81 ayat (2) Undang-Undang Nomor 35 tahun 2014 Tentang Perubahan atas Undang-Undang RI Nomor 23 Tahun 2002 tentang Perlindungan Anak.

Pertimbangan hakim dalam membuktikan unsur "setiap orang" telah berpendapat bahwa yang dimaksud dengan "setiap orang" dalam unsur ini adalah subjek hukum selaku pendukung hak dan kewajiban, baik manusia/ orang (natuurlijke personen) ataupun badan hukum (rechts personen), dalam hal ini yaitu korporasi.

Setiap orang pada Pasal 81 ayat (2) Undang-Undang Nomor 35 tahun 2014 Tentang Perubahan atas Undang-Undang RI Nomor 23 Tahun 2002 tentang Perlindungan Anak bukanlah hanya anak saja tapi dapat juga bukan anak. Pada Pasal ini yang ditekankan adalah korban merupakan anak. Anak yang dihadapkan ke persidangan merupakan orang perseorangan atau orang pribadi yang menurut keterangan Anak dan keterangan para saksi, identitasnya benar sebagaimana tercantum dalam surat dakwaan, sehingga tidak terdapat kekeliruan mengenai orangnya dan hakim berpendapat bahwa unsur setiap orangtelah terpenuhi.

Untuk membuktikan unsur setiap orang yang menunjuk Anak sebagai pelaku tindak pidana sebagaimana didakwakan kepadanya oleh Jaksa Penuntut Umum, maka seharusnya melihat teori pemidanaan dan pertanggungjawaban pidana dalam pembuktian dipersidangan. Tindak pidana atau delik merupakan suatu perbuatan yang mengandung unsur "perbuatan atau tindakan yang dapat dipidana" dan unsur "pertanggungjawaban pidana kepada pelakunya", sehingga untuk menentukan siapa pelaku tindak pidana maka harus dibuktikan terlebih dahulu perbuatan yang dilakukan oleh pelaku tersebut telah memenuhi kedua unsur delik tersebut, baru kemudian dibuktikan unsur setiap orang sebagai pelaku tindak pidana tersebut, sehingga dapat disimpulkan bahwa sesuai teori pemidanaan maka perbuatan pelaku harus dibuktikan terlebih dahulu, setelah terbukti perbuatannya kemudian dibuktikan siapa pelakunya.

Praktek peradilan di Indonesia terdapat dua pendapat, dimana pendapat pertama menyatakan bahwa "barang siapa/setiap orang" merupakan unsur delik, sedangkan pendapat yang kedua menyatakan bahwa bukan merupakan unsur delik, bahwa pendapat pertama yang menyatakan "barang siapa/setiap orang" merupakan unsur delik maka harus 
dibuktikan dipersidangan dengan alat-alat bukti yang menjelaskan bahwa benar orang yang dihadapkan dipersidangan sebagai Terdakwa tersebut adalah benar-benar terbukti sebagai pelaku delik, sedangkan pendapat kedua yang menyatakan bahwa "barang siapa/setiap orang" tidak merupakan unsur delik melainkan unsur dari pasal, dimana pada setiap pasal selalu diawali dengan "barang siapa/setiap orang", hal itu sudah cukup menunjukkan sebagai pelaku tindak pidana ketika oleh Penyidik disangka, oleh Penuntut Umum didakwa dan diperiksa sebagai terdakwa dipersidangan, sehingga tidak memerlukan pembuktian, cukup yang dibuktikan adalah perbuatannya saja, sehingga di dalam praktek kedua pendapat di atas dipergunakan, hal tersebut tergantung dari kasus yang dihadapi, jika ada sangkalan bahwa Terdakwa tersebut bukan sebagai pelaku delik, tetapi orang lain, maka perlu pembuktian untuk mematahkan sangkalan/alibi dari Terdakwa tersebut.

Pembuktian unsur dengan sengaja melakukan tipu muslihat, serangkaian kebohongan, atau membujuk anak melakukan persetubuhan dengannya atau dengan orang lain, mengandung beberapa kriteria secara alternatif karena menggunakan tanda baca koma dan kata-kata "atau", sehingga untuk terbuktinya unsur tersebut tidak perlu terpenuhi semua kriteria unsur dalam pasal ini oleh perbuatan Anak tetapi cukup apabila salah satu kriteria dari unsur dalam pasal ini terpenuhi secara alternatif maka terbuktilah unsur ini.

Penerapan unsur dengan sengaja pada perkara ini didasarkan oleh hakim dengan merujuk pada Memorie van Toelichting, yang dimaksud "dengan sengaja" atau opzet adalah willens en weten, yaitu seseorang yang melakukan sesuatu perbuatan dengan sengaja, harus menghendaki (willen) perbuatan itu, serta harus menginsyafi/mengerti (weten) akan akibat dari perbuatan itu, artinya bahwa seorang pelaku dapat dianggap sudah melakukan kejahatannya dengan sengaja, apabila ia memang benar-benar berkehendak untuk melakukan kejahatan tersebut dan mengetahui tentang maksud dari perbuatannya itu sendiri.

Dalam hal seseorang melakukan sesuatu dengan sengaja dapat di bedakan 3 (tiga) corak sikap batin, yang menunjukkan tingkatan atau bentuk dari kesengajaan itu, sebagai berikut:

1. Kesengajaan sebagai maksud untuk mencapai suatu tujuan ;

2. Kesengajaan dengan sadar kepastian ;

3. Kesengajaan dengan sadar kemungkinan ; 
Unsur pasal ini adalah untuk membuktikan perbuatan pidana yang dilakukan oleh Anak dan pertanggungjawabannya berdasarkanfakta-fakta hukum yang terungkap dipersidangan.Demikian juga pada perkara nomor 11/Pid.Sus-Anak/2018/PN Pmn anak juga membujuk agar anak korban mau bersetubuh dengannya, dengan cara memberikan janji dan membujuk rayu anak korban.

Unsur selanjutnya adalah Melakukan persetubuhan dengannya atau dengan orang lain. Pada perkara ini setelah membujuk dan membohongi anak korban kemudian terjadi persetubuhan antara Anak dengan anak korban setelah anak berjanji akan menikahi anak korban. Persetubuhan yang terjadi terbukti dari hasil visum yang dilakukan terhadap anak korban. Berdasarkan dari fakta hukum tersebut telah nyata bahwa rangkaian perbuatan tersebut dilakukan oleh Anak dengan sengaja untuk mencapai suatu tujuan yaitu memenuhi dan memuaskan nafsu birahinya telah membujuk Anak korban untuk bersetubuh dengannya.

Pada perkaranomor 11/Pid.Sus-Anak/2018/PN Pmn Hakim berkesimpulan Anak yang bernama Julian SaputraPanggilan Juliandalam perkara ini telah memenuhi syarat untuk dikualifikasikan sebagai Subyek Hukum dalam suatu perbuatan pidana dan unsur ini telah terpenuhi.

Unsur dengan sengaja melakukan tipu muslihat, serangkaian kebohongan, atau membujuk anak melakukan persetubuhan dengannya atau dengan orang lain, Hakim berpendapat bahwa unsur kedua ini adalah unsur yang bersifat alternatif, dimana apabila dapat dibuktikan bahwa Terdakwa telah melakukan salah satu atau beberapa anasir perbuatan dari keseluruhan anasir perbuatan yang tercantum dan diatur di dalam unsur kedua tersebut, yang mana masing-masing dari anasir perbuatan dimaksud dapat berdiri sendiri guna dikualifikasikan sebagai elemen pembentuk delik yang sempurna, namun demikian ternyata Hakim telah memberikan pengertian berlebihan yang tidak terkait dengan pembuktian unsur kedua pasal ini yaitu : "melakukan kekerasan", "tidak berdaya", "ancaman kekerasan", "memaksa" dan "cabul", sedangkan unsur pokok pengertian tentang persetubuhan tidak diuraikan dalam putusan.

Selanjutnya Hakim menghubungkan pengertian tersebut dengan perbuatan yang dilakukan oleh Anak, dalam konteks ini telah terjadi kekeliruan dalam menyebutkan uraian pengertian tindak pidana persetubuhan dalam pertimbangan hakim dalam pembuktian 
dakwaan alternatif kesatu dimana larangan melakukan perbuatan cabul ditentukan dalam pasal 76 E Undang-undang Nomor 35 Tahun 2014 dengan ketentuan pidana diatur dalam pasal 82 ayat (1), walaupun demikian dalam kesimpulan terakhirnya Hakim telah menyatakan perbuatan persetubuhan tersebut telah sah terpenuhi yaitu bahwa perbuatan yang telah dilakukan oleh Anak terhadap Anak Korban sebagai "unsur yang dengan sengaja membujuk Anak melakukan persetubuhan dengannya" dinyatakan telah sah terpenuhi, maka perbuatan Anak Julian SaputraPanggilan Juliandinyatakan telah terbukti secara sah dan meyakinkan melakukan tindak pidana sebagaimana didakwakan dalam dakwaan alternatif kesatu tersebut, maka Anak dinyatakan bersalah tentang hal itu.

Penerapan hukum dapat disimpulkan bahwa Hakim kurang cermat dalam menyusun redaksi pengertian-pengertian perbuatan dalam unsur yang dipakai sebagai dasar pertimbangan hukum tentang perbuatan yang dilakukan oleh Anak, walaupun demikian secara keseluruhan telah dipertimbangkan dari berbagai sisi untuk mengambil keputusan yang terbaik bagi masa depan Anak.

\section{Pertimbangan Hakim Dalam Penerapan Pidana Pada Perkara Nomor. 3/Pid.Sus- Anak/2018/PN Pmn. dan Perkara Nomor 11/Pid.Sus-Anak/2018/PN Pmn.}

Dalam menjatuhkan putusan hakim harus memuat pertimbangan-pertimbangan hukum yang diperoleh dari fakta-fakta yang terungkap dalam persidangan berdasarkan alat bukti yang sah sebagaimana ditentukan dalam Pasal 184 KUHAP yaitu: keterangan saksi, keterangan ahli, surat, petunjuk dan keterangan terdakwa, ditegaskan dalam Pasal 14 ayat (1) dan ayat (4) Undang-undang Nomor 48 Tahun 2009 tentang Kekuasaan Kehakiman, yang menyatakan bahwa putusan diambil berdasarkan sidang permusyawaratan Hakim yang bersifat rahasia dan setiap Hakim wajib menyampaikan pertimbangan atau pendapat tertulis terhadap perkara yang sedang diperiksa dan menjadi bagian yang tidak terpisahkan dari putusan, kecuali perkara dalam peradilan anak yang diperiksa dan diputus oleh Hakim tunggal berdasarkan Pasal 44 ayat (1), Pasal 47 ayat (1) dan Pasal 50 ayat (1) UndangUndang Nomor 11 Tahun 2012.

Pertimbangan Hakim dalam menjatuhkan putusan merupakan dasar atau landasan bagi Hakim untuk menentukan keyakinan Hakim itu sendiri dalam menentukan kesalahan terdakwa dan pembuktian dalam proses persidangan, pembuktian memiliki asas minimum 
pembuktian yang dipergunakan sebagai pedoman dalam menilai cukup tidaknya terdakwa, dipertegas dengan pasal 183 KUHAP yang menyatakan Hakim tidak boleh menjatuhkan pidana kepada seseorang kecuali dengan sekurang-kurangnya dua alat bukti yang sah ia memperoleh keyakinan bahwa suatu tindak pidana benar-benar terjadi dan bahwa terdakwalah yang melakukannya. Dengan demikian maka seseorang baru dapat dinyatakan bersalah dan di jatuhkan pidana apabila terbukti secara sah dan meyakinkan bersalah melakukan tindak pidana dengan sekurang-kurangnya dua alat bukti yang sah.

Berdasarkan analisis di atas, dalam proses persidangan telah dilaksanakan sesuai dengan acara persidangan anak, dilaksanakan dalam persidangan tertutup untuk umum, seluruh petugas dalam persidangan tidak mengenakan atribut dan anak didampingi oleh petugas dari Bapas dan orang tua anak. Selanjutnya hasil dalam persidangan tersebut diperoleh fakta-fakta hukum yang dipakai sebagai dasar pertimbangan-pertimbangan Hakim dalam memutus perkara tersebut dan ternyata dalam pertimbangan-pertimbangan Hakim tersebut perbuatan Anak telah memenuhi semua unsur pasal yang didakwakan kepadanya, maka penulis berpendapat bahwa pertimbangan Hakim dalam penjatuhan putusan pidana terhadap Anak dalam Putusan Nomor 11/Pid.Sus-Anak/2018/PN Pmn telah sesuai, yaitu telah memperhatikan dasar mengadili, dasar memutus, dan juga telah mempertimbangkan nilai-nilai yang hidup dalam masyarakat.

Bahwa dengan pertimbangan-pertimbangan hukum Hakim Pengadilan Negeri Pariaman yang memeriksa dan mengadili perkara 3/Pid.Sus-Anak/2018/PN Pmn. dan perkara 11/Pid.Sus-Anak/2018/PN Pmn. telah mempertimbangkan bahwa ketentuan Pasal 81 ayat (2) Undang-undang Nomor 23 Tahun 2002 tentang Perlindungan Anak, tidak hanya terdiri atas pidana badan yang mengandung unsur perampasan kemerdekaan akan tetapi memuat jenis pidana yang lain yaitu dalam bentuk penjatuhan denda maka berdasarkan ketentuan Pasal 71 ayat (3) Undang-undang Nomor 11 Tahun 2012 tentang Sistem Peradilan Pidana Anak, pidana denda dimaksud haruslah diganti dengan pelatihan kerja yang mana pelaksanaan pelatihan kerja tersebut haruslah sedemikian rupa disesuaikan dengan usia Anak sebagaimana diatur dalam ketentuan Pasal 78 ayat (1) Undang-undang Nomor 11 Tahun 2012 tentang Sistem Peradilan Pidana Anak.

Pertimbangan hukum Hakim tersebut telah diupayakan sedapat mungkin menunjukkan rasa keadilan bagi semua pihak. Meskipun demikian belum tentu pihak- 
pihak yang berperkara merasa puas atas amar putusan yang dijatuhkan kepada Anak tersebut, terlebih lagi dalam kedua perkara tersebut yang terbukti dilanggar oleh Anak adalah pasal yang sama tetapi dalam penjatuhan pidana ternyata ada disparitas dalam perkara tersebut :

- Putusanperkara 3/Pid.Sus-Anak/2018/PN Pmn : Menjatuhkan pidana oleh karena itu terhadap Anak dengan pidana penjara selama 1 (satu) tahun dan 3 (tiga) bulan dalam LPKA (Lembaga Pembinaan Khusus Anak) Provinsi Sumatera Barat di Tanjung Pati dan pelatihan kerja selama 3 (tiga) bulan;

- Putusanperkara 11/Pid.Sus-Anak/2018/PN Pmn : Menjatuhkan pidana kepada Anak dengan pidana penjara selama 1 (Satu) tahun dalam LPKA (Lembaga Pembinaan Khusus Anak) Provinsi Sumatera Barat di Tanjung Pati dan pelatihan kerja yang disesuaikan dengan usia Anak selama 4 (empat) bulan.

Adanya perbedaan putusan tersebut dapat disebabkan karena adanya perbuatan yang berbeda yang dihadapkan kepada Hakim. Selain itu, juga adanya ketidaksamaan pandangan Hakim dalam menilai suatu perkara yang sama atau yang dapat dipersamakan. Perbedaan dalam menentukan pidana dalam prakteknya adalah akibat dari kenyataan, bahwa perbuatan yang di hadapan kepada hakim pidana menunjukkan adanya perbedaan. Hal ini juga menunjukkan bahwa di antara para Hakim sendiri terdapat suatu perbedaan pandangan mengenai penilaian terhadap data-data dalam perkara yang samaataupun yang dapat disamakan. Dengan demikian, faktor yang mengakibatkan timbulnya disparitas putusan Hakim dalam perkara pidana anak sebagai pelakunya adalah dari dalam diri Hakim itu sendiri.Aparat penegak hukum, khususnya Hakim merupakan pilar yang sangat penting dalam sistem peradilan pidana guna menegakkan supremasi hukum.Oleh karena itu, diharapkan Hakim dalam menjalankan tugasnya haruslah benar-benar bersikap profesional dan selalu menjunjung tinggi hukum dan nilai-nilai keadilan.

Salah satu penyebab terjadinya disparitas penjatuhan pidana pada dasarnya dimulai dari hukum itu sendiri, di mana hukum tersebut membuka peluang terjadinya pidana karena adanya batas minimum dan maksimum pemberian hukuman, sehingga Hakim bebas bergerak untuk mendapatkan pidana yang tepat menurut pendapat Hakim itu sendiri.

Sebaliknya apabila ditinjau dari perlindungan korban, Hakim dalam putusan Nomor 3/Pid.Sus-Anak/2018/PN Pmn dan Nomor 11/Pid.Sus-Anak/2018/PN Pmn, 
ternyata dalam pertimbangan hukumnya tidak mempertimbangkan pertanggungjawaban terhadap Anak korban yang mana Anak korban merupakan perempuan yang masih di bawah umur yang patut mendapat perlindungan hukum untuk kelangsungan masa depannya.

Pertimbangan Hakim dalam penerapan pidana pada ke dua perkara diatas terdiri dari pertimbangan yuridis dan non yuridis. Pertimbangan yuridis adalah terpenuhinya unsur unsur yang diterapkan oleh Hakim pada putusannya. pertimbangan unsur "setiap orang" dalam unsur ini adalah subjek hukum. Anak yang dihadapkan ke persidangan merupakan orang perseorangan atau orang pribadi yang menurut keterangan Anak dan keterangan para saksi, identitasnya benar sebagaimana tercantum dalam surat dakwaan,sehingga tidak terdapat kekeliruan mengenai orangnya.

Pertimbangan terhadap unsur dengan sengaja melakukan tipu muslihat, serangkaian kebohongan, atau membujuk anak melakukan persetubuhan dengannya atau dengan orang lain terpenuhi berdasarkan pada alat bukti yang diajukan di persidangan. Alat bukti tersebut adalah keterangan saksi dan petunjuk bahwa memang telah terjadi bujuk rayu dan tipuan yang dilakukan oleh pelaku terhadap korban.

Selanjutnya pertimbangan yuridis atas persetubuhan dimana menurut R. Soesilo yang dimaksud dengan persetubuhan adalah peraduan antara anggota kemaluan laki-laki dan perempuan yang biasa dijalankan untuk mendapatkan anak, jadi anggota laki-laki harus masuk ke dalam anggota perempuan sehingga mengeluarkan air mani, hal ini terbukti dari visum et repertum

Disamping pertimbangan yuridis terdapat juga pertimbangan non yuridis yaitu Anak menyesali perbuatannya dan berjanji tidak akan mengulangi lagi perbuatannya. Anak pelaku merupakan tulang punggung keluarga dalam mencari nafkah. Pertimbangan Hakim yang lain adalah berdasarkan pada rekomendasi pekerja sosial Perlindungan Anak dari Instansi Dinas Sosial Pemberdayaan Perempuan dan Perlindungan Anak Kabupaten Padang Pariamanyang dalam rekomendasinya agar permasalahan ini diselesaikan menurut aturan dan undang-undang yang berlaku mengingat perilaku anak pelaku dan akibat dirasakan oleh anak korban.

Pertimbangan yang sama juga terdapat pada Putusanperkara 11/Pid.SusAnak/2018/PN Pmn yaitu yang pertama tentang umur anak pelaku pada saat melakukan 
perbuatannya pertama kali, ia belum berumur 18 tahun sehingga terpenuhi unsur setiap orang. Selanjutnya Unsur yang dengan sengaja melakukan tipu muslihat, serangkaian kebohongan, atau membujuk Anak melakukan persetubuhan dengannya atau dengan orang lain. Berdasarkan pertautan dan persesuaian diantara keterangan para Saksi, keterangan Anak dan Anak Korban, surat-surat serta setelah mengamati dan meneliti barang-barang bukti yang dihadirkan dimuka persidangan.Persetubuhan yang terjadi dibuktikan dengan adanya pertimbangan hakim terhadap Surat Visum Et Repertum.

Pertimbangan non yuridis pada perkara ini adalah Anak telah menginsyafi serta menyadari akan kesalahan yang telah dilakukannya serta menyesali kesalahan yang telah diperbuatnya itu dan berjanji untuk tidak akan mengulangi lagi kesalahan yang sama dikemudian hari, dan selain itu Anakhanya merupakan lulusan SD sehingga tidak tahu dengan keberadaan Undang-undang tentang Perlindungan Anak.

Pertimbangan lain yang memberatkan adalah penyebab anak melakukan hal tersebut karena Anak sering menonton film porno yang disebabkan kurangnya pengawasan dan perhatian yang dilakukan oleh Orang Tua Anak yang mana hal tersebut membuat pergaulan Anak sehari-harinyamenjadi kurang terkontrol, serta dengan mengingat pula bahwasanya pemidanaan adalah diperlukan guna menanamkan sikap siap untuk bertanggung jawab terhadap Anak atas kesalahan yang telah diperbuatnya itu serta supaya dapat memberikan efek jera kepada Anak maupun segenap komponen masyarakat yang berada disekitarnya, maka Hakim menilai bahwasanya Orang Tua dari Anak untuk saat ini tidak memiliki kemampuan yang cukup guna mendidik, membina serta menjaga tumbuh kembang Anak dengan baik sedangkan Anak itu sendiri dilain pihak masih tetap harus diperhatikan kelangsungan maupun kesinambungan tumbuh kembangnya.

Secara sosiologis dan filosofis pertimbangan Hakim adalah perbuatan terdakwa bertentangan dengan program pemerintah yang sedang giat-giatnya melindungi keselamatan dan kesejahteraan anak-anak serta bertentangan dengan nilai-nilai agama dan adat istiadat yang berlaku di masyarakat setempat. Pertimbangan meringankan secara sosiologis adalah Anak berperilaku sopan dan mengakui terus terang tentang kesalahan dan perbuatan yang telah dilakukannya sehingga memperlancar jalannya persidangan serta Anak masih berstatus anak-anak yang mana masih memiliki masa depan yang panjang dan masih bisa diharapkan untuk dapat mengubah perilaku buruknya tersebut dikemudian hari. 


\section{PENUTUP}

Penerapan pidana terhadap putusan Pengadilan Negeri Pariaman Nomor 3/Pid.SusAnak/2018/PN.Pmn dan Nomor 11/Pid.Sus-Anak/2018/PN.Pmn adalah Penerapan pidana terhadap Anak sebagai pelaku tindak pidana persetubuhan dalam putusan Nomor 3/Pid.Sus-Anak/2018/PN Pmn dan Nomor 11/Pid.Sus-Anak/2018/PN Pmn, Berdasarkan fakta-fakta hukum yang terungkap dalam persidangan telah memenui unsur yang terdapat pada Pasal 81 ayat (2) Undang Undang Nomor 35 Tahun 2014 tentang perubahan Undang-Undang Nomor 23 Tahun 2002 tentang Perlindungan Anak, sehingga Hakim menjatuhkan Putusan pidana penjara selama1 (satu) tahun dan 3 (tiga) bulandalam LPKA(Lembaga Pembinaan Khusus Anak)Provinsi Sumatera Barat di Tanjung Patidan pelatihan kerja selama 3 (tiga) bulan pada Perkara Nomor 3/Pid.Sus-Anak/2018/PN Pmn dan Putusan pidana penjara selama 1 (Satu) Tahun dalam LPKA(Lembaga Pembinaan Khusus Anak)Provinsi Sumatera Barat di Tanjung Patidan pelatihan kerja yang disesuaikan dengan usia Anak selama 4 (Empat) Bulan pada Perkara Nomor 11/Pid.SusAnak/2018/PN Pmn. Kedua Pertimbangan hukum Hakim dalam menjatuhkan sanksi pidana penjara terhadap Anak adalah pertimbangan-pertimbangan hukum secara yuridis maupun keadaan sosial Anak dan lingkungannya.

\section{DAFTAR PUSTAKA}

\section{Buku Teks :}

M.Sholehuddin, Sistem Sanksi Dalam Hukum Pidana (Ide Dasar Double Track Systemdan Implementasinya), Raja Grafindo Persada, Jakarta, 2004.

Maidin Gultom, Perlindungan Hukum Terhadap Anak, Refika Aditama, Bandung, 2010

Sri Sutatiek, Rekonstruksi Sistem Sanksi Dalam Hukum Pidan Anak di Indonesia, Aswaja Pressindo, Jakarta, 2013.

\section{Peraturan Undang-Undang :}

Undang-Undang Nomor 11 Tahun 2012 Tentang Sistem Peradilan Pidana Anak.

Undang-Undang Republik Indonesia Nomor 23 Tahun 2002 Tentang Perlindungan Anak.

Undang-Undang Nomor 48 Tahun 2009 Tentang Kekuasaan Kehakiman.

Undang-Undang Nomor 35 tahun 2014 Tentang Perubahan atas Undang-Undang RI Nomor 23 Tahun 2002 tentang Perlindungan Anak. 